\title{
STATUS OF ACTIVITY BASED COSTING SYSTEM IN SELECTED DAIRY INDUSTRIES OF NEPAL Shankar Prasad Bhandari*
}

\begin{abstract}
Profits and productivity both accelerate by reducing costs through better use of resources. In the current context of globalization, Nepalese Dairies should find out the ways to improve the quality of products along with the strategies of reducing existing costs. This study reveals that Dairy plants are using traditional costing system to recover their overhead cost. However, 37 percent were in favor of $A B C$ in their future plan, 63 percent were satisfied with their existing system of cost accounting. They did not support implementation of $A B C$ in future. Thus the existing system of costing in Dairy industry of Nepal is not effective neither to raise higher rate of profit nor productivity.
\end{abstract}

Key words: Activity-based costing; Traditional costing, Cost reduction, Activities

\section{INTRODUCTION}

In the present milieu of liberalization, Nepalese products should be competitive in the domestic market with the products modern and technologically advanced countries. The production cost of milk and milk products is higher in Nepal as compared to India and other Asian countries. Milk production of Nepal can be considered as a sub-sector agriculture which enhance both income and employment of the farmers. Dairy industries are potential in Nepal. These industries can contribute significantly higher national income. However the strategies of reducing cost and increasing productivity are still unresolved. These issues justify cost reduction strategies of Dairies and Activity Based Costing System.

\section{STATEMENT OF THE PROBLEM}

Traditional cost-based measures were developed earlier, when direct labour costs were variable. The labour cost was accounted as a major portion of production cost. Those measures were appropriate to large scale organizations for mass production which includes mostly variable cost. However, labour is largely a fixed and indirect cost which has become a large part of total cost in most organizations. These indirect costs are incurred to acquire resources needed to provide a wide variety of activities, each with different cost drivers.

Activity based costing system (ABC) is an important tool in management accounting. This system highlights on cost and consumption of activities throughout the organization and accurate information for decisions. It follows the allocation of overheads based on their activities rather than the volume. $\mathrm{ABC}$ is gaining importance in organizations for a better understanding of cost behaviour and cost control. The use of $\mathrm{ABC}$ system could help to reduce the existing cost of different products and 
increase in the overall productivity of the organizations. This system better is useful for utilizations of existing resources and proper allocation of overhead expenses. Hence present study tries to find out the answers of following questions:

- What is the current practice of recovering the overheads of different Diary products?

- Do the industries intend to change their existing system?

\section{OBJECTIVES OF THE STUDY}

The overall objective of the study is to find out the opinions about the implementation of ABC in Dairies. The specific objectives are:

- $\quad$ To explore the existing practice of overhead cost recovery of different products, and

- $\quad$ To analyze the opinions of Dairy industries for the implementation of $\mathrm{ABC}$ in the future.

There is no correlation among the supporters and oppositions of $\mathrm{ABC}$ of Traditional Costing System.

\section{TERMINOLOGIES}

\section{Traditional Costing System}

Traditional costing system (TCS) measures basically the volume concerned resources such as raw materials, and machine costs. Summarizing all other costs to one or more overhead pools that are then logically allocated to products. It is not reported by activity. It is generally said that TCS tends to over cost high volume products and under cost low volume products. It also ignores non volume activities. This system is an indirect measure of quality and time.

\section{ACTIVITY BASEd COSTING}

Activity based costing system has been introduced as an alternative of Traditional costing systems. It is a process of individually listing and measuring the cost of each activity contributing to the production and delivery of a particular product or service. Many significant overheads are related to specific activities which are relatively independent of production volume. These activities drive the overhead costs and $\mathrm{ABC}$ uses such activities for both production costing and process control. ABC differs from conventional costing in its treatment of nonvolume related overhead costs. It is used to recover the overhead expenses on the basis of activities to diversified products.

\section{METHODOLOGY}

\section{NATURE AND SOURCES OF DATA}

The qualitative information concerning with Activity Based Costing are collected through primary sources. For primary data collection, the information of Dairies has been obtained from the publication of Nepal Dairy Association. The study has employed a questionnaire survey. In respect of questionnaire design, a questionnaire, consisting 11 structured questions relating to the Activity Based Costing was distributed to the financial executives, accountants, owners or persons who are engaged in marketing and quality control activities. Key questions were based on Likert type scale. 


\section{TOOLS SELECTION}

Rank Correlation Coefficient for measuring the association between two variables i.e. supporters and oppositions of $\mathrm{ABC}$ are incorporated. The hypothesis is accepted if observed $\mathrm{p}$ value is more than 0.05 at 5 percent level of significance. The mean values, standard deviations and coefficient of variations are also used in the analysis.

\section{ANALYSIS OF ACTIVITY BASED COSTING: SURVEY RESPONSES}

The present study is concerned with the opinions survey of the respondents from Dairy units which are supporting $\mathrm{ABC}$ or rejecting it to implement in the future. A total of 30 sets questionnaires were distributed in 16 different Dairy industries, 27 respondents from 15 Dairy industries completed the survey. Average work experience of the respondents was not less than 7 years in the company. Survey questionnaires were developed in two sections: Section A, for the general information of Dairies whereas section $\mathrm{B}$, for obtaining the opinions: relating to the activity based costing.

\section{Purchase, Production and Delivery Activities of Dairies}

The analysis reveals that all the Dairy plants are using unit of output or sales volume to recover existing overhead cost. Most of the private Dairies collect their raw milk from the area of Kavre, Banepa, Nagarkot, Bhakundebesi, Teeka Bhairav, Trisuli and Dhading. Few of them like Sitaram, Gokul and Himalaya Dairy are extended their collection to Chitawan, Nawalparasi, and Rupendehi also. DDC collects essential milk from 34 districts of the country covering the area from Panchthar to Kanchanpur. Most of the raw milk is collected in the morning. The dry season starts from the month of Falgun and continues to Ashadh. Daires purchase dry milk, packing materials and other materials, mostly from the local markets.

Pasteurized milk and other milk products are usually produced once a day. The analysis reveals that 22.2 percent have are utilizing their plant capacity more than 75 percent, 40.7 percent are utilized more than 50 percent but less than 75 percent, 29.7.7 percent have utilized more than 25 percent but less than 50 percent, and rest 7.4 percent have used less than 25 percent. The average running hours of majority plants in a day is 3 to 5.99 hours. The delivery system of milk and milk products of these Dairy industries did not find to be similar. Altogether 40.8 percent have used booth agency, 29.6 percent responded direct supply to the retailers and consumers however rest 29.6 percent are implementing both systems.

\section{Control Activities}

Control activity like quality and operation are other major aspects in manufacturing firms. For the test of quality of output in Dairy plants, it is revealed that 37 percent have used quality control engineer in their organizations. altogether 44.4 percent have applied technical staffs (having some training in this field) and rest 18.6 percent from owners' own experience. In the case of operation control performed, 48.2 percent have their response on owners own control, 37 percent by divisional chief, and rest 14.8 have utilized administrative staffs.

Likewise, in store handling, 42 percent have accountants, 38.6 percent by no specific, and rest 19.2 percent from store keeper. Following table present total number of respondents, sum of their response, mean value, standard 
deviation and their coefficient of variation and total response of respondents regarding the vital role of costs in storing. On an average, the mean score for the vital role of cost in storing activities in Dairy industries was calculated as 3.6.The analysis revealed that the respondents have claimed all the items; raw milk ,chemical and spare parts, milk power and packing materials, and milk products as a major cost element in storing activities.

\section{Supporters and Deniers of ABC to Implement in Future}

Following table presents interest of respondents for implementing $\mathrm{ABC}$ in their future plan. Questions were asked to indicate their opinions on 5 point Likert scale ranging from strongly disagrees to strongly agree. Out of total respondents, 37 percent of them have given their consent for implementing $A B C$ in future. The average mean score for the implementation $\mathrm{ABC}$ in Dairy industries is obtained as 3.73. ABC supporters justify their opinion providing the most important reasons that $\mathrm{ABC}$ is more accurate cost information for production and it improves cost control using better performance measures.

Table 1: Perception of the Respondents on Implementation of ABC in Future

\begin{tabular}{|c|c|c|c|c|c|c|}
\hline SN & Items & $\begin{array}{c}\text { No. of } \\
\text { respondents }\end{array}$ & $\begin{array}{c}\text { Sum } \\
\text { of } \\
\text { Ranks }\end{array}$ & Mean & $\sigma$ & $\begin{array}{l}\text { C.V. } \\
(\%)\end{array}$ \\
\hline 1. & $\begin{array}{l}\text { More accurate cost } \\
\text { information for } \\
\text { production }\end{array}$ & 10 & 45 & 4.5 & 0.52 & 11.71 \\
\hline 2. & $\begin{array}{l}\text { Refining decision } \\
\text { making process }\end{array}$ & 10 & 37 & 3.7 & 0.48 & 13.05 \\
\hline 3. & $\begin{array}{l}\text { More accurate } \\
\text { customer profitability } \\
\text { analysis }\end{array}$ & 10 & 31 & 3.1 & 0.31 & 10.19 \\
\hline 4. & $\begin{array}{l}\text { Better cost } \\
\text { classification and } \\
\text { behavior }\end{array}$ & 10 & 37 & 3.7 & 1 & 36.13 \\
\hline 5. & $\begin{array}{l}\text { Improves cost control } \\
\text { using better } \\
\text { performance } \\
\text { measures }\end{array}$ & 10 & 43 & 4.3 & 0.67 & 15.69 \\
\hline 6. & $\begin{array}{l}\text { Better performance } \\
\text { measurement }\end{array}$ & 10 & 37 & 3.7 & 0.67 & 18.24 \\
\hline 7. & Ongoing feedback & 10 & 31 & 3.1 & 0.73 & 23.80 \\
\hline
\end{tabular}

An important finding of the research was; $A B C$ supporters were less satisfied with their existing cost accounting system. That means their existing cost accounting system has not been adequate to fulfill the need for better cost accounting information.

Following table presents the response of respondents regarding the rejecting of $\mathrm{ABC}$ to implement in the future. Questions were asked to indicate their opinion on 5 point Likert scales ranging from strongly disagree to strongly agree. Out of total respondents, 63 percent were ABC deniers. They have 
negative perception for implementing $\mathrm{ABC}$ in future. $\mathrm{ABC}$ deniers justify their opinion providing the most important reasons that they are already satisfied with their existing cost accounting system, ABC implementation being associated with high cost, lack of adequate resources for the implementation, lack of management interest, lack of time to understand and assessment.

Table 2: Perception of Deniers to Implement ABC

\begin{tabular}{|c|c|c|c|c|c|c|}
\hline $\begin{array}{l}\mathbf{S} \\
\mathbf{N}\end{array}$ & Items & $\begin{array}{c}\text { No. of } \\
\text { respondents }\end{array}$ & $\begin{array}{c}\text { Sum } \\
\text { of } \\
\text { Ranks }\end{array}$ & Mean & $\sigma$ & $\begin{array}{l}\text { C.V. } \\
(\%)\end{array}$ \\
\hline 1. & $\begin{array}{l}\text { Satisfied with } \\
\text { existing system }\end{array}$ & 17 & 78 & 4.59 & 0.61 & 13.46 \\
\hline 2. & $\begin{array}{l}\text { Lack of } \\
\text { management } \\
\text { interest }\end{array}$ & 16 & 62 & 3.88 & 1.02 & 26.42 \\
\hline 3. & $\begin{array}{l}\text { ABC } \\
\text { implementation } \\
\text { being associated } \\
\text { with high cost }\end{array}$ & 16 & 67 & 4.19 & 0.65 & 15.64 \\
\hline 4. & $\begin{array}{l}\text { Lack of time to } \\
\text { understand and } \\
\text { assessment of } \mathrm{ABC}\end{array}$ & 17 & 65 & 3.82 & 0.80 & 21.15 \\
\hline 5. & $\begin{array}{l}\text { ABC inadequate to } \\
\text { provide cost } \\
\text { information }\end{array}$ & 15 & 45 & 3 & 0.75 & 25.2 \\
\hline 6. & $\begin{array}{l}\text { Lack of adequate } \\
\text { resources for } \\
\text { implementation }\end{array}$ & 17 & 74 & 4.35 & 0.70 & 16.12 \\
\hline 7. & $\begin{array}{l}\text { Employees will not } \\
\text { accept change }\end{array}$ & 15 & 52 & 3.47 & 0.83 & 24.05 \\
\hline 8. & $\begin{array}{l}\text { Customers' are not } \\
\text { in favor of change }\end{array}$ & 16 & 38 & 2.38 & 0.5 & 21.05 \\
\hline
\end{tabular}

\section{Limitations of TCS: Perceived from ABC Supporters and Deniers}

Following table highlights total number of respondents, sum of their response, mean value, standard deviation and their coefficient of variation and total response of respondents regarding the perceived major limitations of TCS. Questions were asked to the respondents to indicate their opinions on 5 point Likert scale ranging from strongly disagrees to strongly agree. Respondents include both: intended to implement $\mathrm{ABC}$ in future and opposing for the implementation of $\mathrm{ABC}$. The most significant factors having mean value more than 3.43 for the perceived limitations of TCS were: High volume and low technology and overheads (mean value $=4.52$ ), non volume related activities are not considered (mean value $=4.17$ ), no information of quality and cost of customers' service (mean value $=3.54$ ), bias towards labour cost reduction rather than overall productivity (mean value $=3.09$ ), and does not measure the cost of production and services (mean value $=3.0$ ). The table indicated that remaining two factors having mean value less than 3.0 are: no information useful in productivity 
improvement (mean value $=2.96$ ), and no information if productivity improvement efforts yielded significant results (mean value $=2.77$ ).

Table 3: Perception of the Respondents on Perceived Limitations of TCS

\begin{tabular}{|c|c|c|c|c|c|c|}
\hline $\begin{array}{l}\mathbf{S} \\
\mathbf{N}\end{array}$ & Items & $\begin{array}{c}\text { No. of } \\
\text { respondents }\end{array}$ & $\begin{array}{l}\text { Sum of } \\
\text { Ranks }\end{array}$ & Mean & $\sigma$ & $\begin{array}{l}\text { C.V. } \\
(\%)\end{array}$ \\
\hline 1. & $\begin{array}{l}\text { High volume and } \\
\text { low technology and } \\
\text { overheads }\end{array}$ & 27 & 122 & 4.52 & 0.7 & 15.49 \\
\hline 2. & $\begin{array}{l}\text { Non volume related } \\
\text { activities are not } \\
\text { considered }\end{array}$ & 24 & 100 & 4.17 & 0.76 & 18.26 \\
\hline 3. & $\begin{array}{l}\text { No information of } \\
\text { quality and Cost of } \\
\text { customers service }\end{array}$ & 24 & 85 & 3.54 & 0.72 & 20.35 \\
\hline 4. & $\begin{array}{l}\text { Bias towards labour } \\
\text { cost reduction rather } \\
\text { than over all } \\
\text { productivity }\end{array}$ & 22 & 68 & 3.09 & 0.75 & 24.26 \\
\hline 5. & $\begin{array}{l}\text { Does not measure } \\
\text { the cost of } \\
\text { production and } \\
\text { services }\end{array}$ & 26 & 78 & 3 & 0.63 & 21.06 \\
\hline 6. & $\begin{array}{l}\text { No information if } \\
\text { productivity } \\
\text { improvement efforts } \\
\text { yielded significant } \\
\text { results }\end{array}$ & 26 & 72 & 2.77 & 0.65 & 23.50 \\
\hline 7. & $\begin{array}{l}\text { No information } \\
\text { useful in } \\
\text { productivity } \\
\text { improvement }\end{array}$ & 26 & 77 & 2.96 & 0.66 & 22.35 \\
\hline
\end{tabular}

The mean score for the perceived limitation of TCS in Dairy industries has been calculated as 3.43.The Dairies that belong to the ABC supporter and in future plans justified their opinion providing the most important limitations claimed that high volume and low technology, no information of quality and cost of customers service, no information of quality and cost of customers service are the major limitations of exiting cost accounting system

The analysis of the response of perceived limitations from the view point of supporters and deniers of ABC separately is given below: 
Table 4: Perception of the Respondents on Limitations of TCS (Showing Supporters and Deniers)

\begin{tabular}{|c|c|c|c|c|c|c|c|}
\hline $\begin{array}{l}\mathbf{S} \\
\mathbf{N}\end{array}$ & Items & $\mathbf{A B C}$ & $\begin{array}{c}\text { Total of } \\
\text { respondents }\end{array}$ & $\begin{array}{c}\text { Sum } \\
\text { of } \\
\text { Ranks }\end{array}$ & Mean & $\sigma$ & $\begin{array}{l}\text { C.V. } \\
(\%)\end{array}$ \\
\hline \multirow[t]{3}{*}{1.} & \multirow{3}{*}{$\begin{array}{l}\text { High volume } \\
\text { and low } \\
\text { technology } \\
\text { and overheads }\end{array}$} & Supporters & 10 & 50 & 5 & 0 & 0 \\
\hline & & Deniers & 17 & 72 & 4.23 & 0.75 & 17.75 \\
\hline & & Total & 27 & 122 & 4.51 & 0.7 & 15.49 \\
\hline \multirow[t]{3}{*}{2.} & \multirow{3}{*}{$\begin{array}{l}\text { Non volume } \\
\text { related } \\
\text { activities are } \\
\text { not considered }\end{array}$} & Supporters & 10 & 45 & 4.5 & 0.53 & 11.71 \\
\hline & & Deniers & 14 & 55 & 3.93 & 0.83 & 21.07 \\
\hline & & Total & 24 & 100 & 4.17 & 0.76 & 18.26 \\
\hline \multirow[t]{3}{*}{3.} & \multirow{3}{*}{$\begin{array}{l}\text { No } \\
\text { information of } \\
\text { quality and } \\
\text { Cost of } \\
\text { customers } \\
\text { service }\end{array}$} & Supporters & 10 & 35 & 3.5 & 0.85 & 24.26 \\
\hline & & Deniers & 14 & 50 & 3.57 & 0.65 & 18.09 \\
\hline & & Total & 24 & 85 & 3.54 & 0.72 & 20.36 \\
\hline \multirow[t]{3}{*}{4.} & \multirow{3}{*}{$\begin{array}{l}\text { Bias towards } \\
\text { labour cost } \\
\text { reduction } \\
\text { rather than } \\
\text { over all } \\
\text { productivity }\end{array}$} & Supporters & 10 & 33 & 3.3 & 0.82 & 24.94 \\
\hline & & Deniers & 12 & 35 & 2.92 & 0.67 & 22.90 \\
\hline & & Total & 22 & 68 & 3.09 & 0.75 & 24.26 \\
\hline \multirow[t]{3}{*}{5.} & \multirow{3}{*}{$\begin{array}{l}\text { Does not } \\
\text { measure the } \\
\text { cost of } \\
\text { production and } \\
\text { services }\end{array}$} & Supporters & 10 & 33 & 3.3 & 0.48 & 14.64 \\
\hline & & Deniers & 16 & 45 & 2.81 & 0.66 & 23.29 \\
\hline & & Total & 26 & 78 & 3 & 0.63 & 21.07 \\
\hline \multirow[t]{3}{*}{6.} & \multirow{3}{*}{$\begin{array}{l}\text { No } \\
\text { information if } \\
\text { productivity } \\
\text { improvement } \\
\text { efforts yielded } \\
\text { significant } \\
\text { results }\end{array}$} & Supporters & 10 & 29 & 2.9 & 0.32 & 10.89 \\
\hline & & Deniers & 16 & 43 & 2.69 & 0.79 & 29.51 \\
\hline & & Total & 26 & 72 & 2.77 & 0.65 & 23.51 \\
\hline \multirow[t]{3}{*}{7.} & \multirow{3}{*}{$\begin{array}{l}\text { No } \\
\text { information } \\
\text { useful in } \\
\text { productivity } \\
\text { improvement }\end{array}$} & Supporters & 10 & 27 & 2.7 & 0.48 & 17.89 \\
\hline & & Deniers & 16 & 50 & 3.13 & 0.73 & 22.98 \\
\hline & & Total & 26 & 77 & 2.96 & 0.66 & 22.35 \\
\hline
\end{tabular}

Thus, the analysis of the empirical evidence revealed that $\mathrm{ABC}$ supporters and $\mathrm{ABC}$ deniers have different views regarding the extent to which they are satisfied with their currently used cost accounting system. 
Table 5: Rank Correlation Coefficient

\begin{tabular}{|l|l|l|c|c|}
\hline & & & DENIER & SUPPORT \\
\hline \multirow{5}{*}{ Spearman's rho } & DENIER & $\begin{array}{l}\text { Correlation } \\
\text { Coefficient }\end{array}$ & 1.000 & 0.655 \\
\cline { 3 - 5 } & & Sig. (2-tailed) & $\cdot$ & 0.111 \\
\cline { 3 - 5 } & $\mathrm{N}$ & 7 & 7 \\
\cline { 3 - 5 } & SUPPORT & $\begin{array}{l}\text { Correlation } \\
\text { Coefficient }\end{array}$ & 0.655 & 1.000 \\
\cline { 3 - 5 } & Sig. (2-tailed) & 0.111 &. \\
\cline { 3 - 5 } & $\mathrm{N}$ & 7 & 7 \\
\hline
\end{tabular}

Using descriptive statistics (SPSS 17), following table shows the Spearman's rank correlation coefficient. The correlation coefficient value 0.655 revealed that two variables were moderately correlated. The $\mathrm{p}$ value at 5 percent level of significance observed 0.111 which is more than $\alpha=.05$. Thus, the hypotheses of no correlation has been accepted.

This finding indicated that the Dairies which have supported ABC as a future prospect were less satisfied with their existing cost accounting system in comparison to those that did not intend to consider implementation of $\mathrm{ABC}$.

\section{Non Product Level Activities}

Non product level activities include activities which include various other cost objects such as facilities, customers, corporate, business units, etc. The common activity in any organization include purchasing, customer order processing, quality control, material handling, production control, inspection, distribution and maintenance. Out of total 30_sets distributed, response received from 27 respondents. Following table reveals total number of respondents, sum of their response, mean value, standard deviation and their coefficient of variation. 
Table 6: Perception of the respondents on Support Activities

\begin{tabular}{|c|c|c|c|c|c|c|}
\hline $\begin{array}{l}\mathbf{S} \\
\mathbf{N}\end{array}$ & Items & $\begin{array}{c}\text { No. of } \\
\text { respondents }\end{array}$ & $\begin{array}{c}\text { Sum } \\
\text { of } \\
\text { Ranks }\end{array}$ & Mean & $\sigma$ & $\begin{array}{l}\text { C.V. } \\
(\%)\end{array}$ \\
\hline 1. & $\begin{array}{l}\text { Milk and Milk } \\
\text { powder purchase } \\
\text { related activities }\end{array}$ & 27 & 135 & 5 & 0 & 0 \\
\hline 2. & $\begin{array}{l}\text { Milk, Milk } \\
\text { powder, } \\
\text { Chemicals and } \\
\text { Packing material } \\
\text { handling activities }\end{array}$ & 27 & 121 & 4.48 & 0.643 & 14.348 \\
\hline 3. & $\begin{array}{l}\text { Transportation of } \\
\text { raw materials }\end{array}$ & 27 & 106 & 3.93 & 0.267 & 6.801 \\
\hline 4. & $\begin{array}{l}\text { Production control } \\
\text { activities }\end{array}$ & 27 & 104 & 3.85 & 0.534 & 13.863 \\
\hline 5. & $\begin{array}{l}\text { Inspection. and } \\
\text { Quality control } \\
\text { activities }\end{array}$ & 27 & 99 & 3.67 & 0.48 & 13.091 \\
\hline 6. & $\begin{array}{l}\text { Production } \\
\text { scheduling(set up) } \\
\text { activities }\end{array}$ & 25 & 90 & 3.6 & 0.5 & 13.889 \\
\hline 7. & $\begin{array}{l}\text { Plant and vehicles } \\
\text { repair and } \\
\text { maintenance } \\
\text { activities }\end{array}$ & 26 & 90 & 3.46 & 0.905 & 26.144 \\
\hline 8. & $\begin{array}{l}\text { Customer order } \\
\text { processing (on } \\
\text { time delivery) } \\
\text { activities }\end{array}$ & 27 & 84 & 3 & 0.941 & 31.367 \\
\hline 9. & $\begin{array}{l}\text { Employees } \\
\text { Welfare and safety } \\
\text { activities }\end{array}$ & 27 & 79 & 2.93 & 0.267 & 9.125 \\
\hline $\begin{array}{c}10 \\
.\end{array}$ & $\begin{array}{l}\text { Competitors } \\
\text { monitoring } \\
\text { activities }\end{array}$ & 27 & 68 & 2.52 & 0.893 & 35.457 \\
\hline
\end{tabular}

On an average, the mean score for the non product activities in Dairy industries was calculated as 3.64.The above analysis revealed that the respondents have claimed all the activities leaving employees welfare and safety activities and competitors monitoring activities as the major support activity in Dairy units. Finally it has been concluded that these activities must be considered as major cost pool for determining the cost drivers of the Dairies.

\section{SUMMARY AND CONCLUSIONS}

Activity based costing system is a technique which is used to recover the overhead expenses on the basis of activities. This system helps for the proper 
allocation of indirect expenses and finding the most appropriate amount of production cost and improving the productivity. The data analysis revealed that out of total respondents, 63 percent of them were against the implementation of $\mathrm{ABC}$ in future and they were satisfied with their existing system of cost accounting. Altogether 37 percent of the respondents were in favor of $\mathrm{ABC}$ in their future plan. They were not satisfied with the existing costing system and supported ABC.

So far as the perception of limitation of traditional costing is concerned, the empirical evidence reveals that $\mathrm{ABC}$ deniers and $\mathrm{ABC}$ supporters have different views regarding the extent to which they were satisfied with their currently used cost accounting system. The $\mathrm{p}$ value at 5 percent level of significance has found significant and the hypothesis of no association between two variables has been accepted. This finding indicated that the Dairies which have supported $\mathrm{ABC}$ as a future prospect were less satisfied with their existing cost accounting system in the comparison with those that did not intend to consider implementation of $\mathrm{ABC}$.

The given support activities leaving employees welfare and safety activities and competitors monitoring activities were identified as major cost pool for determining the cost drivers of the Dairies. Out of them, Milk and milk powder purchase related activity is found to be the most significant factor in Dairy units. The analysis concluded that these activities must be considered as major cost pool for determining the cost drivers of the Dairies.

\section{WORKS CITED}

Clarke, P. and Mullins, T. (2001). "Activity based costing in the non manufacturing sector in Ireland." Irish Journal of Management. 22(2), 1-18.

Cohen, S., Venieris, G. and Kaimenaki, E. (2005). "ABC: adopters, supporters, deniers and unawares." Managerial Auditing Journal. $\mathrm{http} / \mathrm{www}$.emerald.com.

Cotton, and Jackman, S. (2002). "Activity based costing: not as "easy as ABC". Chartered Accountant Journal of New Zealand, 81(4), 35.

Frank Chen F. (1996). "Activity-based approach to justification of advanced factory management systems." Industrial Management and Data Systems. volume 96, number 2, pp. 17-24.

Gunasekaran, A., Marri H.B. and Grieve R.J. (1999). "Justification and implementation of activity based costing in small and medium-sized enterprises." Logistics Information Management. Volume 12, Number Kaplan, R.S. (1983).

"Measuring performance: A new challenges for managerial accounting research." The Accounting Review, Vol. 58, pp. 386-394, http/www.emerald.com

Levin, R.I. and Rubin, D.S. (1998). Statistics for management. Tan Prints (I) Pvt. Ltd., Delhi.

Siegel, S. and Castellan, N.J (1988). "Nonparametric statistics for the behavioral sciences." McGraw -Hill Book Company, New York.

Simmonds, K. (1981). "Strategic management accounting." Journal of Management accounting. 59(4).

Sohal, A.S. and Chung, W.W.C. (1998). Activity based costing in manufacturing: two case studies on implementation. http/www. emerald. Com. 